\title{
VALIDATION OF METHOD FOR DETERMINING THE ISOELECTRIC POINT OF PROTEIN SOLUTIONS
}

\author{
Gabriela MACOVESCU*, Ciprian CHELARU, Mădălina IGNAT, Luminiţa ALBU, Dana GURĂU
}

INCDTP - Division: Leather and Footwear Research Institute, 93 Ion Minulescu St, Bucharest, 3, 031215, Romania, elamac22@yahoo.com

Received: 05.12.2017

Accepted: 07.03.2018

https://doi.org/10.24264/Ifj.18.1.7

\section{VALIDATION OF METHOD FOR DETERMINING THE ISOELECTRIC POINT OF PROTEIN SOLUTIONS}

ABSTRACT. This paper presents the validation of a method for determining the isoelectric point of collagen hydrolysates used to obtain biomaterials for medical use produced in the Collagen Department of INCDTP - Division ICPI. The advantage of the presented method is that it is easy to apply, as the Zeta potential is the key parameter controlling electrostatic interactions in particle dispersions. The technique used to measure particle movement velocity in the Malvern Zetasizer Nano instrument series is Laser Doppler Velocimetry (LDV). It is an accepted method for measuring electrophoretic mobility of particles in the solution and by calculating the Zeta potential of protein solutions through extrapolation, the isoelectric point of the protein solution is determined.

KEY WORDS: biomaterials, collagen, isoelectric point, method validation

\section{VALIDAREA METODEI PENTRU DETERMINAREA PUNCTULUI IZOELECTRIC LA SOLUTIIILE PROTEICE}

REZUMAT. Lucrarea prezintă validarea unei metode de determinare a punctului izoelectric al hidrolizatelor de colagen folosite la obținerea de biomateriale pentru uz medical produse în Departamentul Colagen al INCDTP - Sucursala ICPI. Metoda prezentată are avantajul că este ușor de aplicat, potențialul Zeta fiind parametrul cheie care controlează interacțiunile electrostatice în dispersiile particulelor. Tehnica utilizată pentru măsurarea vitezei de deplasare a particulelor în seria de instrumente Malvern Zetasizer Nano este Laser Doppler Velocimetry (LDV). Este o metodă acceptată pentru măsurarea mobilității electroforetice a particulelor în soluție și din calcularea potențialului Zeta al soluțiilor proteice prin extrapolare se determină punctul izoelectric al soluției proteice.

CUVINTE CHEIE: biomateriale, colagen, punct izoelectric, validare metodă

VALIDATION DE LA MÉTHODE POUR DÉTERMINER LE POINT ISOÉLECTRIQUE DE SOLUTIONS PROTÉIQUES

RÉSUMÉ. L'article présente la validation d' une méthode de détermination du point isoélectrique des hydrolysats de collagène utilisés pour l'obtention de biomatériaux à usage médical produits dans le Département Collagène d'INCDTP - ICPI. La méthode présentée a l'avantage d'être facile à appliquer, le potentiel Zêta étant le paramètre clé qui contrôle les interactions électrostatiques dans les dispersions de particules. La technique utilisée pour mesurer la vitesse du mouvement des particules dans la série Malvern Zetasizer Nano est la vélocimétrie laser Doppler (LDV). C'est une méthode acceptée pour mesurer la mobilité électrophorétique des particules dans la solution et en calculant le potentiel Zêta des solutions protéiques par extrapolation, on détermine le point isoélectrique de la solution protéique.

MOTS CLÉS: biomatériaux, collagène, point isoélectrique, validation de la méthode

\footnotetext{
" Correspondence to: Gabriela MACOVESCU, INCDTP - Division: Leather and Footwear Research Institute, 93 Ion Minulescu St, Bucharest, 3, 031215, Romania, elamac22@yahoo.com
} 


\section{INTRODUCTION}

The quality of products for medical use is a particularly complex concept as they embed physical-chemical, biochemical, microbiological and toxicological characteristics with profound implications on life and are an essential factor for metabolic processes and for the balance of the body.

Proteins are the most versatile macromolecules in living systems and have crucial functions in all biological processes [1]. They function as catalysts, carry and store other molecules such as oxygen, provide mechanical support and immunity, generate movement, send nervous impulses, control the growth and differentiation of organisms. Proteins are linear polymers made up of monomer units, called amino acids, their functions being defined by the sequence of amino acids from the protein polymer and its three-dimensional structure. Proteins are thus the embodiment of the transition from the three-dimensional world of molecules capable of various activities.

Proteins contain a wide range of functional groups, and when they are combined in different sequences, this range of functional groups is the wide spectrum of the protein function.

Collagen has a distinct composition compared to other proteins, as it is rich in glycine, proline and hydroxyproline, and does not contain cystine and tryptophan. As a result of prolonged heating in water, collagen undergoes partial hydrolysis, which occurs with structural changes, due to the breaking of inter-chain bonds, transforming into collagen hydrolysate.

The tertiarystructure of collagen represents an advanced degree of spatial organization. It is the result of interactions between the $R$ residues of amino acids in the polypeptide chains, which can establish different types of intramolecular bonds such as: hydrogen bonds, ionic bonds, covalent bonds, van der Waals forces, dipoledipole interactions.

As with amino acids [2], due to the presence of functional groups ionized in protein molecules, they are characterized by well-defined values of their isoelectric point [3] (or isoelectric $\mathrm{pH}$ - pl or $\mathrm{pHi}$ ) that is defined as that $\mathrm{pH}$ value at which the global electrical charge of the molecule is null. This physical-chemical parameter presents a practical importance, underlying electrophoretic methods [4] of separation and determination of different protein fractions in biological fluids. The isoelectric points [5] of the proteins oscillate between very large limits (2-12.5) depending on the number of acidic or alkaline groups that predominate on the surface of the macromolecule and do not depend on their molecular mass.

Due to their amphoteric character, proteins can neutralize small amounts of acidic or alkaline substance, thus having the role of buffer, thereby helping to maintain the acid-alkaline balance of the body. In general, the amphoteric character is imprinted by the free $-\mathrm{NH}_{2}$ and $-\mathrm{COOH}$ groups which are not involved in the peptide bonds. If there are several dicarboxylic amino acids in the protein molecule, then the molecule will behave like a weak acid, and those where diamine amino acids predominate behave like weak alkalis. Although there is an equal number of amino and carboxyl groups in a molecule, and theoretically the molecule should be neutral, in fact, due to the much higher degree of ionization of the carboxyl group compared to the amino group, the protein molecule will have a weak acid character, comprising, in its solution, protein amphoteric ions, protein anions and protons $\left(\mathrm{H}^{+}\right)$ [6].

By acidification, the equilibrium of the reaction moves towards the formation of protein cations. At a certain concentration of hydrogen ions, the protein becomes electrically neutral since the amine and carboxyl groups are equally dissociated. At that time, amphoteric ions, $-\mathrm{H}^{+}$hydrogen protons, $-\mathrm{HO}^{-}$hydroxyl ions will be found in the solution. The $\mathrm{pH}$ at which the solution of a protein contains anions and cations in equal proportion is called isoelectric point, being a very important protein constant.

Each protein at the isoelectric point has a specific behavior, having solubility, chemical reactivity, viscosity, osmotic pressure and hydration of the minimum colloidal particles. The precipitation of the protein at the isoelectric point is maximum however, and under the influence of the electric current there is no displacement, which makes it possible to be determined by electrophoretic and potentiometric methods.

A study has been conducted on the methods of analysis used to determine the isoelectric $\mathrm{pH}$ of the solutions in order to 
develop a method of analysis for the qualitative assessment of protein solutions for obtaining collagen-based materials for medical use.

The first definitions of the isoelectric point and the first preoccupations for the development of the methods for its identification were conceptualized from the beginning of the $20^{\text {th }}$ century, by W.B. Hardy (1899-1900), Leonor Michaelis (1922), and Søren Peder Lauritz Sørensen, K. Linderstrom-Lang and Lund [6, 7].

In the case of gelatin, the isoelectric point was first determined by Leonor Michaelis and W. Grineff [8], who determined it at a concentration of hydrogen ions $\left[\mathrm{H}^{+}\right]$comprised between 1.6 $\mathrm{X} 10^{-5}$ and $3.5 \times 10^{-5}$, the average being $2.5 \times 10^{-5}$, and the corresponding pH of 4.80, 4.46 and 4.60 .

Most of the subsequent determinations for gelatin were based on cataphoresis measurements, and the isoelectric point was not exactly localized. Thus, Jacques Loeb [1] interpreted his observations on the variation of the physical and chemical properties of gelatin, indicating an isoelectric point at $\mathrm{pH}$ 4.7.

Kraemer and Dexter [9] showed that previous observations were inconsistent and determined the isoelectric point at $\mathrm{pH}$ 5.0, which they located for calf skin gelatins as the $\mathrm{pH}$ at which the light dispersion is the maximum (Tyndall effect). They showed, however, that the resulting numbers depend very much on the origin of the skin and on the method of preparing the gelatin.

In order to avoid discrepancies due to the differences between gelatins, the Leather and Gelatin Division of the American Chemical Society presented an isoelectric point study on samples prepared as specified by a committee $[10,11]$. The study showed that the method of obtaining and purifying gelatin [12] is very important.

The isoelectric point of such gelatin was reported by Sheppard and Houck [13] at $\mathrm{pH}$ $4.9 \pm 0.10$ by electrical field migration and at $\mathrm{pH}$ $4.9 \pm 0.05$ by both Tyndall effect assessment, and by precipitation with alcohol.

Consequently, it has been found useful to investigate the standard gelatin behavior with respect to the turbidity of standard gelatin solutions in a pH range of 4 to 6 with acetate buffer. In each case, the turbidity was maximal towards the middle of the series, so that from these observations the $\mathrm{pH}$ of maximum turbidity was set at $4.85 \pm 0.03$.

By definition, the most direct way to determine the isoelectric point is to determine the $\mathrm{pH}$ for zero migration in an electric field.

Migration was carried out in various types of cells by confirming Smoluchowski's theory.

Zeta potential is the key parameter that controls electrostatic interactions in particle dispersions and as such is an important factor in understanding the stability of colloidal dispersions [14]. It can be used to optimize suspension and emulsion formulations and to help establish their long-term stability.

The potential that occurs at relative movement of phases in contact is called electrokinetic potential (६).

At the passage of the electric current through the emulsion, the opposing sign mobile ions from the diffuse layer are directed towards the respective electrodes. The electrokinetic potential, $\xi$, that appears was calculated according to the Helmholtz-Smoluchowski relationship [15]:

$$
\xi=\frac{\eta \cdot u}{\varepsilon \cdot \varepsilon_{0} \cdot H}
$$

where: $\mathbf{u}$ is the velocity of particles; $\eta-$ medium viscosity; $\varepsilon$ - electrical permittivity; $\varepsilon_{0}$ - vacuum permittivity $\left(8.85 \times 10^{-2} \mathrm{~F} / \mathrm{m}\right) ; \mathbf{H}$ - potential gradient

Electrophoresis study enabled determination of particle charge in the emulsion and assessment of electrokinetic potential value, $\xi$.

The most important factor affecting the Zeta potential is the $\mathrm{pH}$. Therefore, a graphical representation of the Zeta potential $[16,17]$, depending on the $\mathrm{pH}$ will be positive at low $\mathrm{pH}$ and negative at high $\mathrm{pH}$. The point where the graph goes through zero is the Zeta potential. This point is called the isoelectric point [18] and is very important for practical reasons. It is normally the point where the colloidal system is the least stable.

As a result of the literature study on ways to determine the isoelectric point 
of proteins, it was chosen to measure electrophoretic mobility. The method is based on the determination of the Zeta potential, of the electrical conductivity depending on the $\mathrm{pH}$ variation of some protein solutions [19].

\section{EXPERIMENTAL}

\section{Method Principle}

Protein molecules have an amphoteric character. Depending on the concentration of $\mathrm{H}^{+}$ions in the solution, the molecule is positively or negatively charged. The concentration of hydrogen ions at which the protein molecule has an equal number of positive and negative charges is called an isoelectric point. In most cases, the dissociation constant of the protein as an acid exceeds the dissociation constant of the same protein as an alkali. A particle in aqueous solution is usually negatively charged.

By gradually acidifying such a solution, the degree of dissociation of the protein [20, 21], as alkali increases (the neutralization of
$\mathrm{OH}^{-}$ions). In this way an equal concentration of positive and negative ions can be achieved. At the isoelectric point [22], the colloidal particles become electrically neutral; being less stable, the protein solution precipitates very easily.

The concentration of hydrogen ions at which the isoelectric point is achieved [23] is a protein-specific value that varies between the $\mathrm{pH}$ range of 4.1 to 6.7 .

\section{Equipment and Reagents}

* Zetasizer Nano ZS from MALVERN

* orion star a 211 ph-meter from THERMO SCIENTIFIC

* $0.1 \mathrm{~N}$ sodium acetate

* $0.1 \mathrm{~N}$ acetic acid solution

* $1 \%$ protein solution

* 90\% methyl alcohol

\section{Work Method}

In order to calculate the isoelectric point [24], $0.1 \mathrm{~N}$ sodium acetate, $0.1 \mathrm{~N}$ acetic acid solution, and $1 \%$ protein solution are added to 6 test tubes, according to proportions given in Table 1.

Table 1: Proportions of solutions required to measure the isoelectric point

\begin{tabular}{lllllll}
\hline \multicolumn{1}{l}{ Added reagents $(\mathrm{ml})$} & \multicolumn{7}{c}{ Test tube number } \\
& 1 & 2 & 3 & 4 & 5 & 6 \\
\hline $0.1 \mathrm{~N}$ sodium acetate & 2 & 2 & 2 & 2 & 2 & 1,2 \\
$0.1 \mathrm{~N}$ acetic acid & 0,25 & 0,5 & 1 & 2 & 4 & 4,8 \\
Distilled water & 3,75 & 3,5 & 3 & 2 & - & - \\
$1 \%$ protein solution & 2 & 2 & 2 & 2 & 2 & 2 \\
\end{tabular}

The $\mathrm{pH}$ of protein solutions is measured using the $\mathrm{pH}$-meter before and after adding the protein solution in order to see the variation it causes, if applicable, then the electrophoretic mobility is measured using the Zetasizer Nano.

$\mathrm{pH}$ variation is plotted depending on Zeta potential and extrapolated to obtain the isoelectric point at 0 potential.
Methyl alcohol is added to the test tubes to highlight the isoelectric point by means of turbidity.

\section{RESULTS AND DISCUSSIONS}

$\mathrm{pH}$ measurements of protein solutions were determined using ORION STAR A $211 \mathrm{pH}$-meter from THERMO SCIENTIFIC presented in Figure 1. 


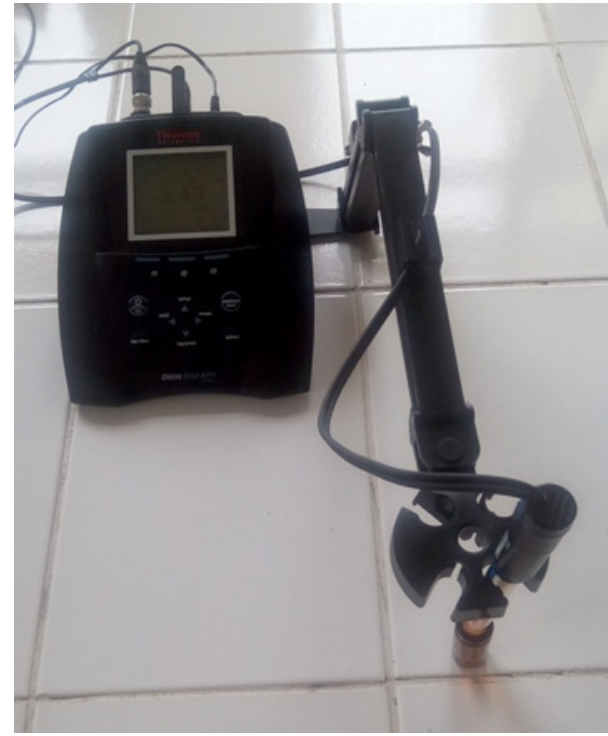

Figure 1. ORION STAR A $211 \mathrm{pH}$-meter

Electrophoretic mobility was highlighted through the variation of Zeta potential and electrical conductivity with the Zetasizer Nano ZS from MALVERN, presented in Figure 2.

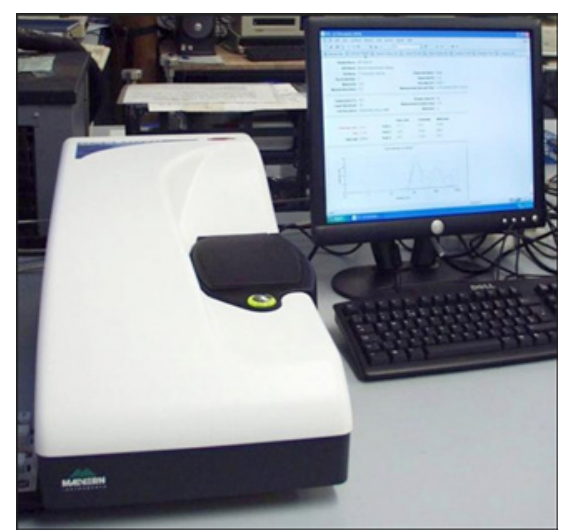

Figure 2. Zetasizer Nano ZS
The essence of a classic microelectrophoresis system is an electrode cell at each end to which a potential is applied. The particles move to the opposite charge electrode, their velocity being measured and expressed as unit of the field, as mobility.

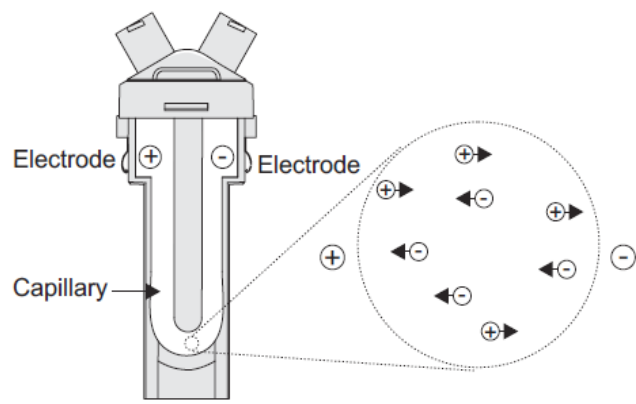

Figure 3. Micro-electrophoresis cell

The technique used to measure the particle movement velocity in the Malvern Zetasizer Nano series is Laser Doppler Velocimetry (LDV).

For all measurements, a $40 \mathrm{~V}$ field was applied over a $10 \mathrm{~mm}$ electrode spacing at $25^{\circ} \mathrm{C}$. Three repeated measurements were performed on each sample to verify the repeatability of the results. All measured electrophoretic mobilities were converted into Zeta potential using the Smoluchowski formula.

Electrophoresis study enabled determination of particle charge in the emulsion and assessment of electrokinetic potential value, $\boldsymbol{\xi}$. 


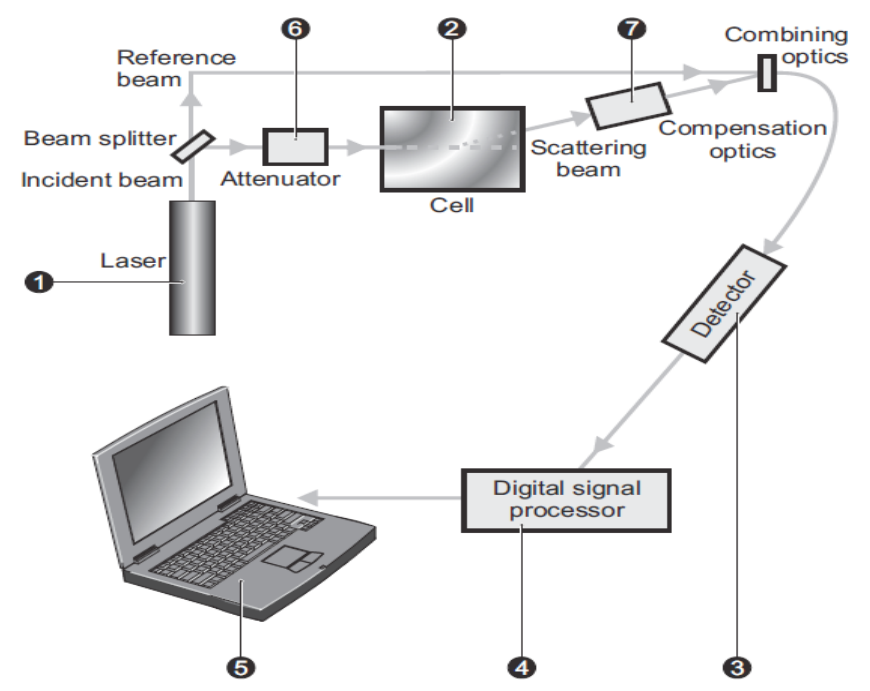

Figure 4. Zetasizer Nano ZS operation flowchart

When an electric field is applied to the cell (2), all the particles moving through the measurement volume will cause light intensity fluctuations detected with a frequency proportional to the particle speed.

A detector (3) sends this information to a digital signal processor (4). This information is then transmitted to a computer (5) in which the Zetasizer Nano software produces a frequency spectrum from which the electrophoretic mobility is calculated, and hence the Zeta potential.

An "attenuator" (6) is used to reduce the intensity of the laser and hence to reduce the intensity of the dispersion.

Resulting data are plotted to calculate the isoelectric point by extrapolation.

In the resulting solutions, the isoelectric point is also highlighted by adding methyl alcohol in the test tubes and noticing turbidity that indicates aggregation of molecules, with maximum coagulation at the isoelectric point.

Alcohol and some organic solvents fix (extract) water that hydrates the protein molecule; water-free micelles flocculate. About $8-10 \mathrm{ml}$ alcohol are usually necessary.

After adding the alcohol, the test tube content is stirred. Test tubes are left to rest for 30 minutes and the test tube with the highest amount of precipitate is marked.
The corresponding $\mathrm{pH}$ value is the isoelectric $\mathrm{pH}$ of gelatin [17] that must comply with the one found in literature, of 4.7.

An acetic buffer, acetic acid $\left(\mathrm{CH}_{3} \mathrm{COOH}\right)$ and sodium acetate $\left(\mathrm{CH}_{3} \mathrm{COONa}\right)$ mixture, was used to determine the isoelectric point.

As the acetic acid dissociation in the presence of the strong $\mathrm{CH}_{3} \mathrm{COONa}$ electrolyte, which has a joint anion with the acid, is almost completely suppressed, the equilibrium concentration of the nondissociated molecules $\left[\mathrm{CH}_{3} \mathrm{COOH}\right]$ can be taken as the initial acid concentration.

\section{Data Analysis}

Statistical calculations were performed in Excel 2010, also used to calculate isoelectric points, standard deviation, bias, repeatability, reproducibility, method reliability and accuracy. All statistical tests were conducted at a confidence level of $95 \%$ and $\mathrm{k}=2$.

\section{Validation of Method}

Validation of an analytical method is the process by which it is established by laboratory studies if that method meets the conditions for the analytical applications for which it was developed.

Validation is therefore an important step in determining the repeatability, 
reproducibility, and reliability of the method as it can confirm whether the method is suitable for use for a particular system.

To validate the method, six series of standard gelatin solutions were prepared, namely gelatin solution from MERCK Millipore of the same concentration, and the following were calculated:

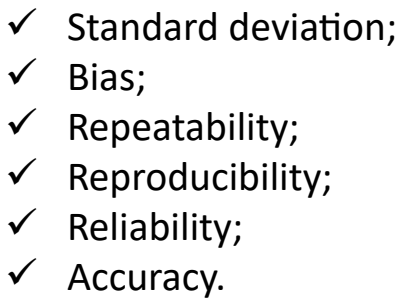

$\checkmark$ Bias;

Repeatability

$\checkmark$ Reliability;

$\checkmark$ Accuracy.

Table 2: Composition of tested solutions from each series

\begin{tabular}{lllllll}
\hline Added reagents $(\mathrm{ml})$ & \multicolumn{7}{c}{ Test tube number } \\
& 1 & 2 & 3 & 4 & 5 & 6 \\
\hline $0.1 \mathrm{~N}$ sodium acetate & 2 & 2 & 2 & 2 & 2 & 1.2 \\
$0.1 \mathrm{~N}$ acetic acid & 0.25 & 0.5 & 1 & 2 & 4 & 4.8 \\
Distilled water & 3.75 & 3.5 & 3 & 2 & - & - \\
Resulting pH & 5.525 & 5.229 & 4.915 & 4.593 & 4.271 & 3.951 \\
1\% gelatin solution & 2 & 2 & 2 & 2 & 2 & 2 \\
Resulting pH after adding gelatin solution & 5.528 & 5.227 & 4.917 & 4.589 & 4.275 & 3.955 \\
Appearance & Clear & Clear & Clear & Clear & Clear & Clear \\
& solution & solution & solution & solution & solution & solution \\
\hline
\end{tabular}

Using the $\mathrm{pH}$ meter, the $\mathrm{pH}$ values were read before and after the addition of the protein solution. $\mathrm{pH}$ variations range from 0.003 to $0.004 \mathrm{pH}$ units, are insignificant, demonstrating stability in the buffer solutions used.

Samples were introduced into the ZETASIZER cell to measure electrophoretic mobility, namely Zeta potential, electrical conductivity and then the results were extrapolated to determine the isoelectric point.

The results and graphic representation for the isoelectric point determination of the 6 series of gelatin solutions are presented in Tables 3-8.

Table 3: Determination of isoelectric point - Gelatin 1

$1 \%$ gelatin solution in water (powder gelatin)

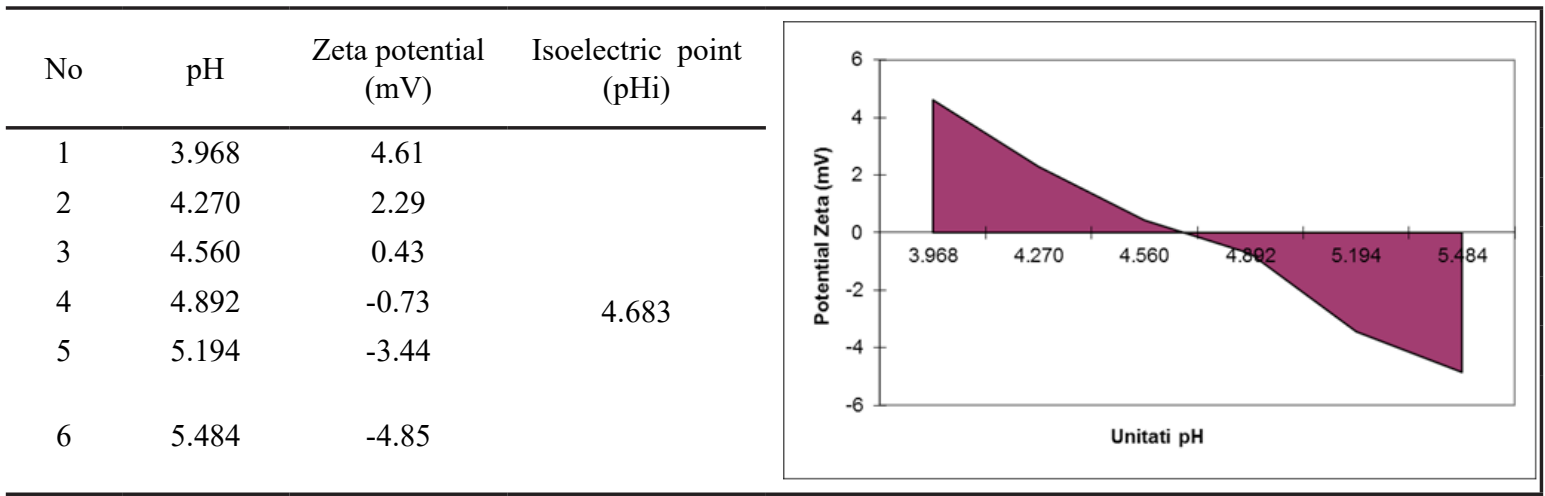


Table 4: Determination of isoelectric point - Gelatin 2

$1 \%$ gelatin solution in water (powder gelatin)

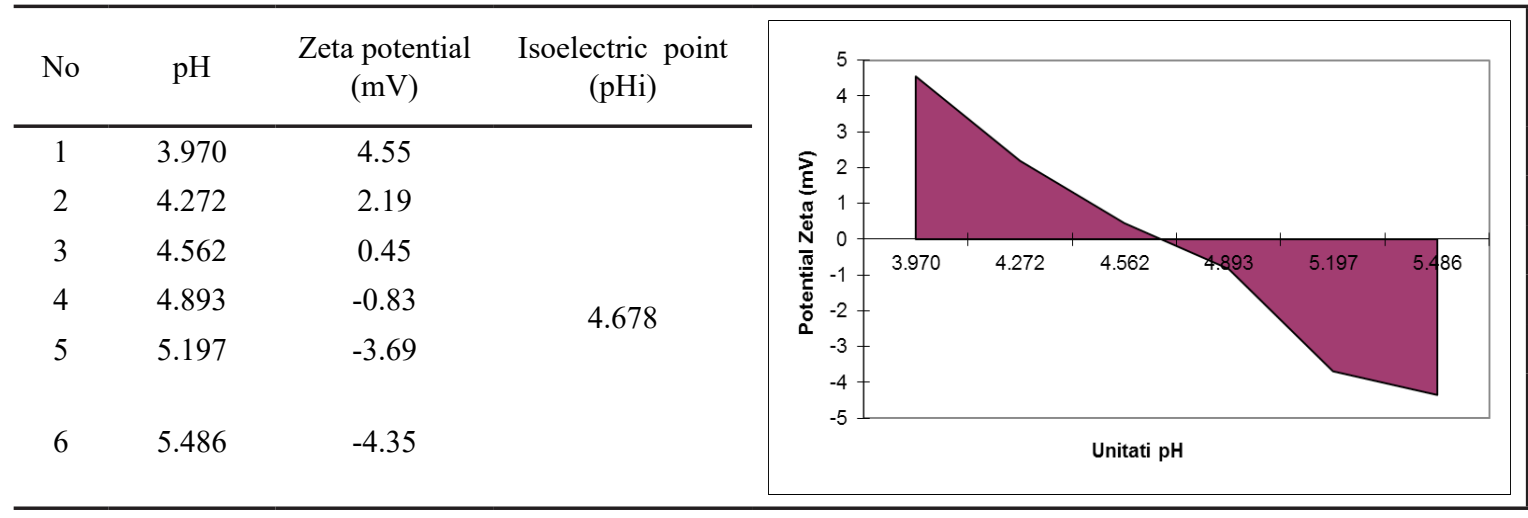

Table 5: Determination of isoelectric point - Gelatin 3

$1 \%$ gelatin solution in water (powder gelatin)

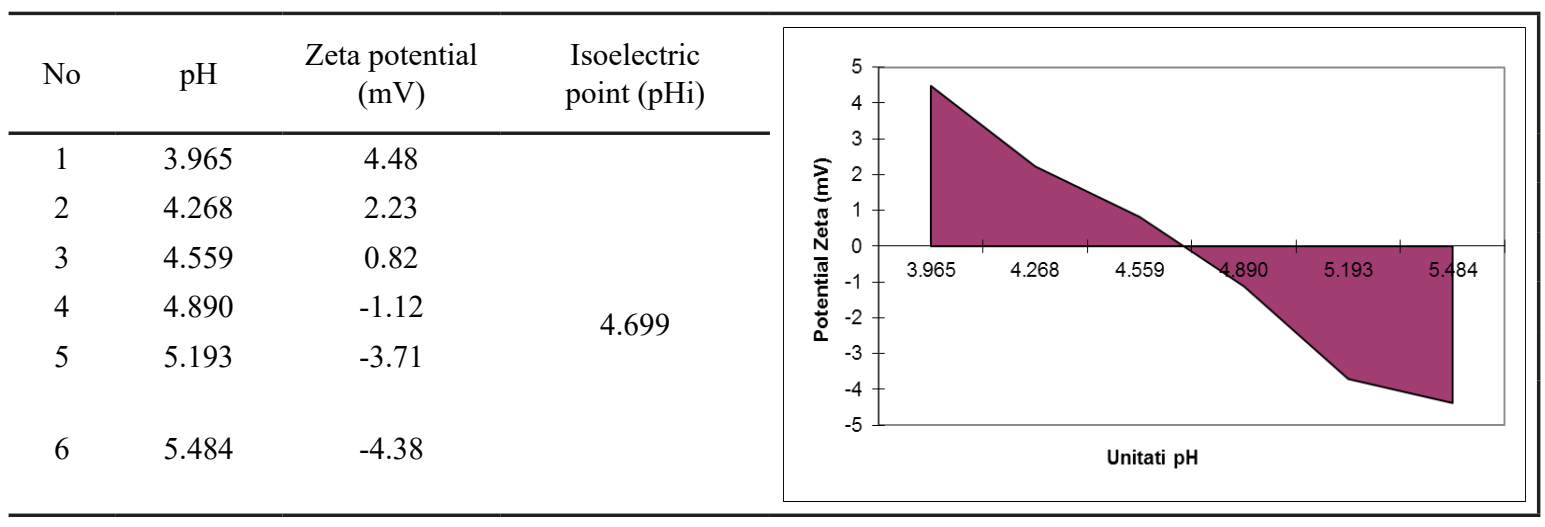

Table 6: Determination of isoelectric point - Gelatin 4

$1 \%$ gelatin solution in water (powder gelatin)

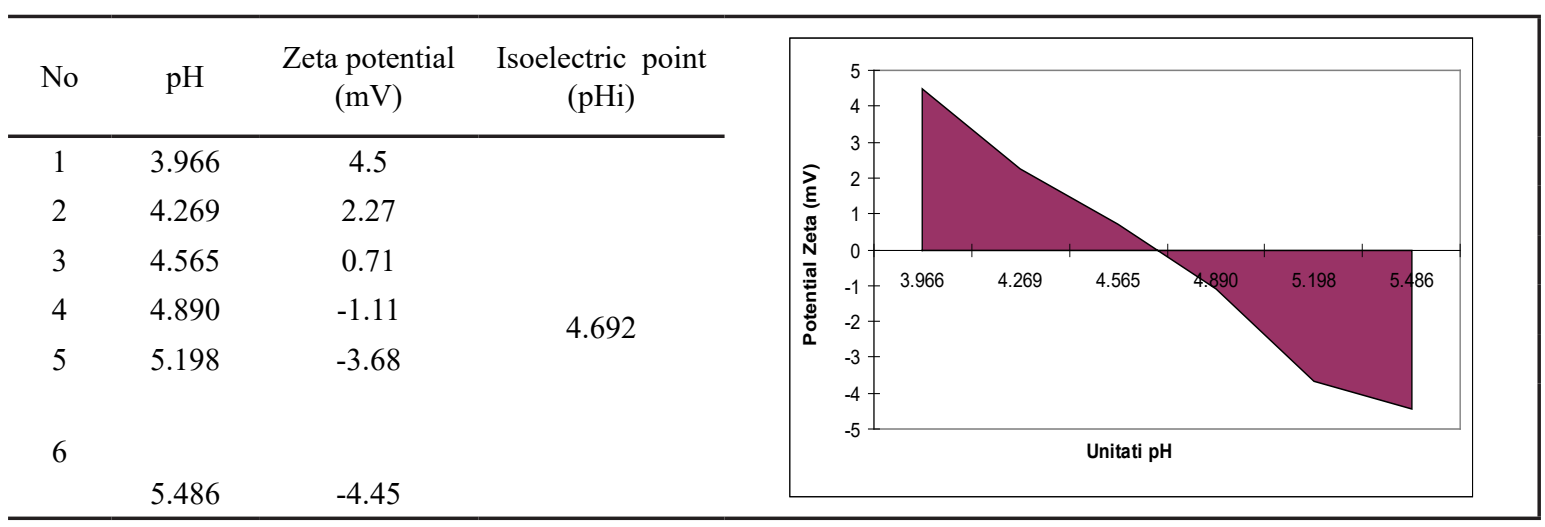


Table 7: Determination of isoelectric point - Gelatin 5

$1 \%$ gelatin solution in water (powder gelatin)

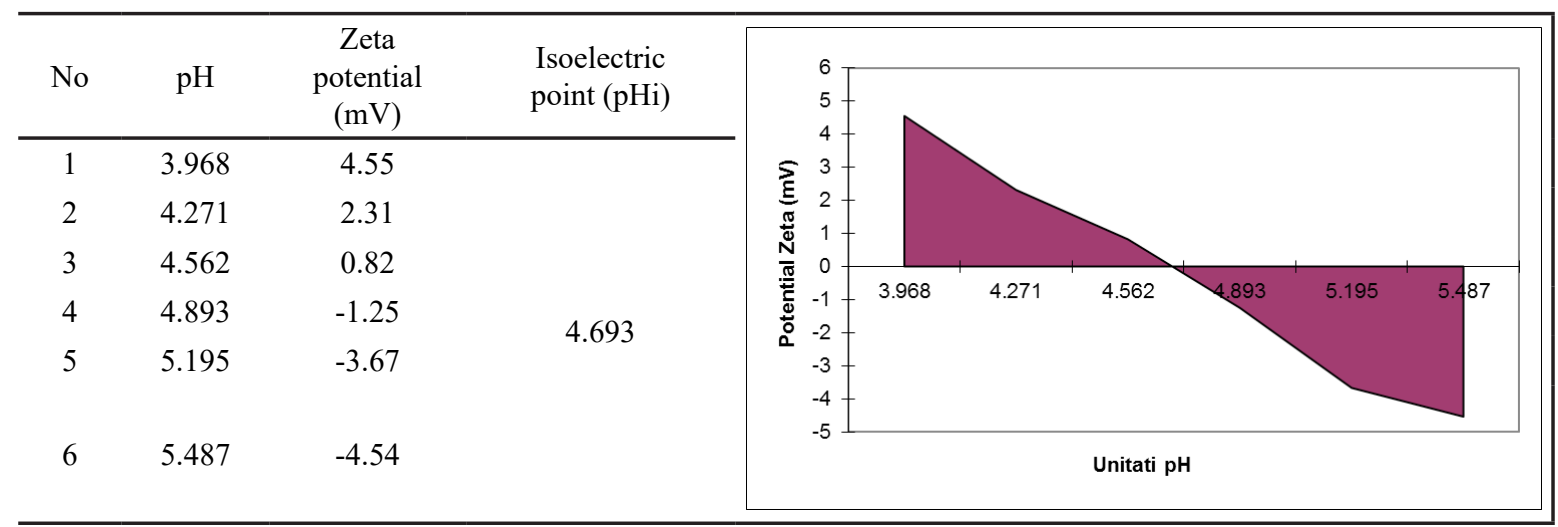

Table 8: Determination of isoelectric point - Gelatin 6

$1 \%$ gelatin solution in water (powder gelatin)

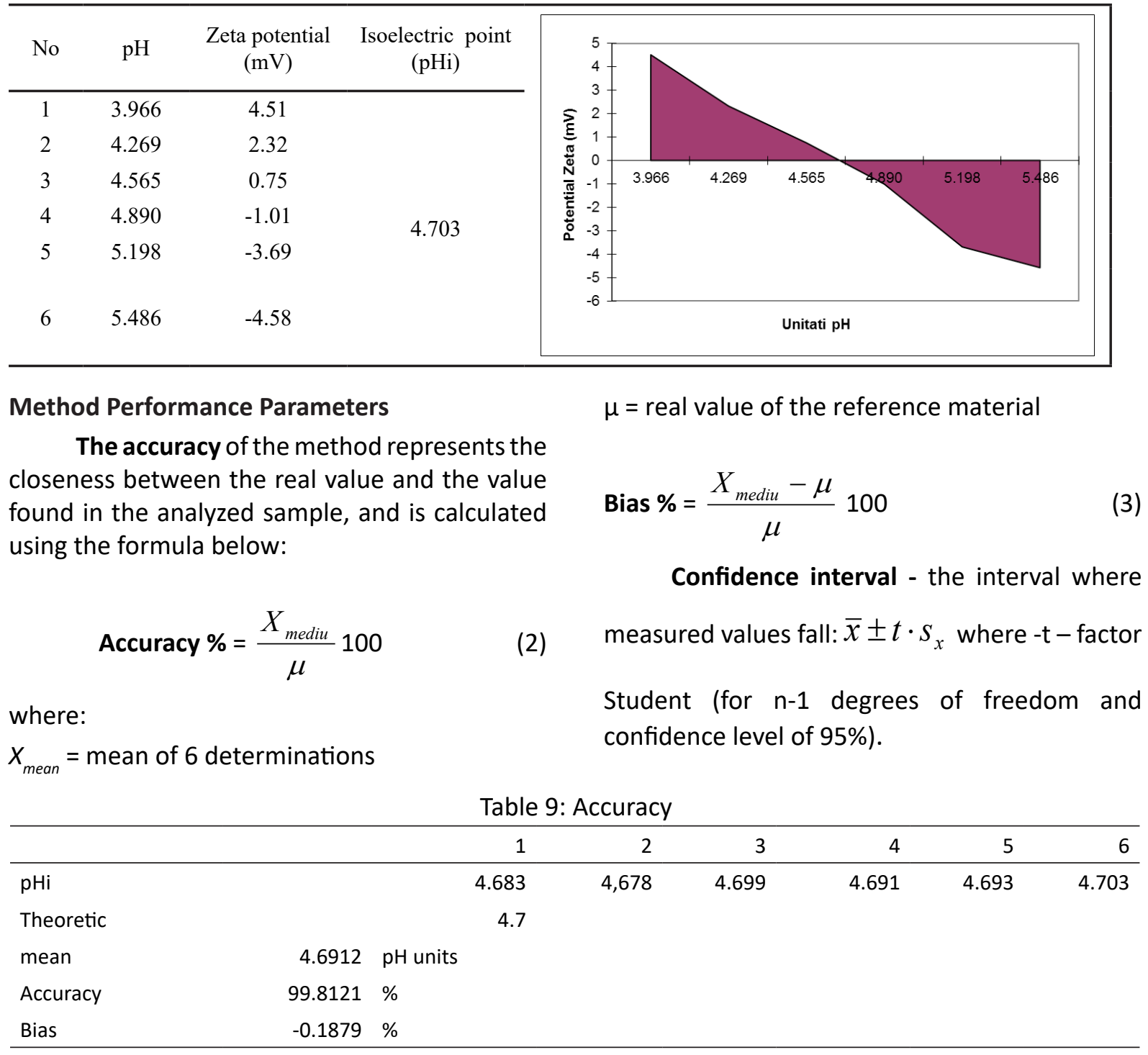


Reliability represents the degree of approximation between the results of independent tests obtained under established conditions and is expressed by the coefficient of variation, CV, for a repeated analysis which is calculated with the formula:

$$
\text { CV (RSD) \% = (s / Xmean }) 100
$$

(4) $s=$ standard deviation.

Table 10: Reliability

\begin{tabular}{|c|c|c|c|c|c|c|c|c|}
\hline & & & 1 & 2 & 3 & 4 & 5 & 6 \\
\hline $\mathrm{pHi}$ & & & 4.683 & 4.678 & 4.699 & 4.691 & 4.693 & 4.703 \\
\hline Theoretic & & & 4.7 & & & & & \\
\hline mean & 4.6912 & $\mathrm{pH}$ units & & & & & & \\
\hline Standard deviation & 0.0094 & $\mathrm{pH}$ units & & & & & & \\
\hline CV (RSD) & 0.2011 & $\%$ & & & & & & \\
\hline
\end{tabular}

Repeatability is a measure of the degree of scattering within a confidence interval of the results obtained from the measurement performed by the same analyst under the same working conditions.

Table 11: Repeatability

\begin{tabular}{|c|c|c|c|c|c|c|c|c|}
\hline & & & 1 & 2 & 3 & 4 & 5 & 6 \\
\hline $\mathrm{pHi}$ & & & 4.683 & 4.678 & 4.699 & 4.691 & 4.693 & 4.703 \\
\hline Theoretic & & & 4.7 & & & & & \\
\hline mean & 4.6912 & $\mathrm{pH}$ units & & & & & & \\
\hline Standard deviation & 0.0094 & $\mathrm{pH}$ units & & & & & & \\
\hline r & 0.0264 & $\mathrm{pH}$ units & & & & & & \\
\hline RSDr & 0.0020 & $\%$ & & & & & & \\
\hline
\end{tabular}

Analyses of Protein Solutions

Four samples of atomized $\mathrm{HO} 8$ hydrolysate, and gelatin capsules used for packaging medical use products, were studied and characterized physically and chemically. The results are presented in Table 12.

Table 12: Characterization of collagen products for medical use

\begin{tabular}{lcccc}
\hline Characteristics & Dry substance, $\%$ & Ash*, $\%$ & Total nitrogen* \% & Appearance \\
\hline COLLAGEN HYDROLYSATE HO8-1 & & & & \\
COLLAGEN HYDROLYSATE HO8-2 & 95,64 & 0,45 & 17,70 & Light yellow powder \\
COLLAGEN HYDROLYSATE HO8-3 & 96,24 & 0,36 & 17,52 & Light yellow powder \\
COLLAGEN HYDROLYSATE HO8-4 & 97,02 & 0,24 & 17,63 & Light yellow powder \\
Gelatin capsules & 95,91 & 0,41 & 17,56 & Light yellow powder \\
\hline
\end{tabular}

Samples, from which $1 \%$ collagen hydrolysate solutions in water were made, were distributed in 6 test tubes with the proportions in Table 3. Results were presented in Tables 13-17. 
Table 13: Determination of isoelectric point - Hydrolysate H08-1

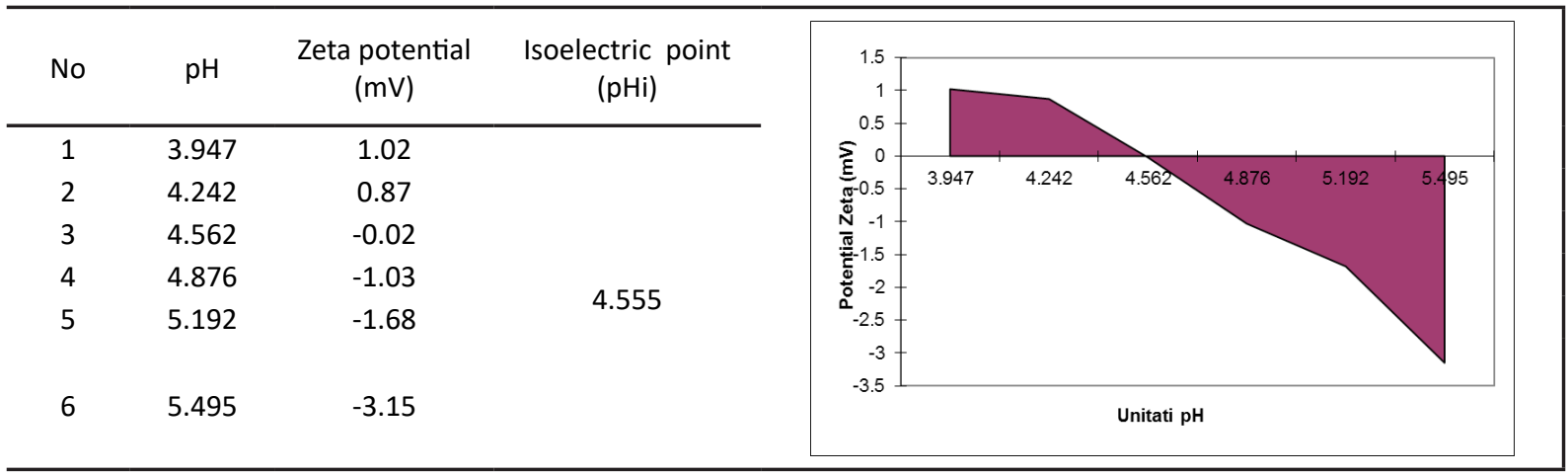

Table 14: Determination of isoelectric point - Hydrolysate H08-2

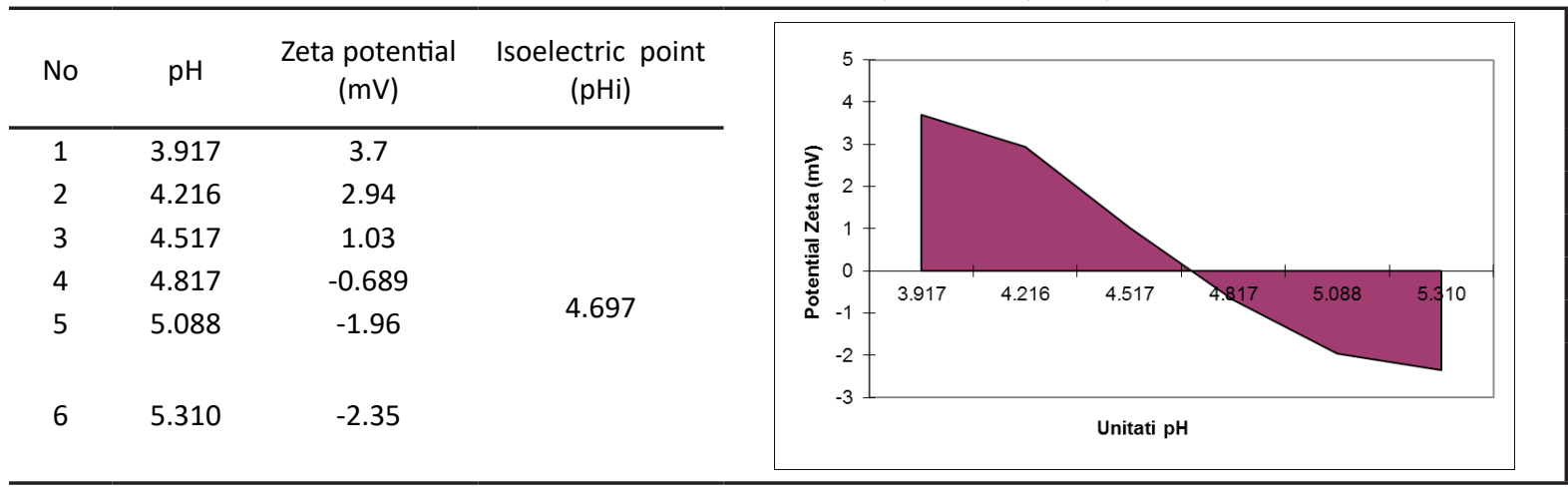

Table 15: Determination of isoelectric point - Hydrolysate H08-3

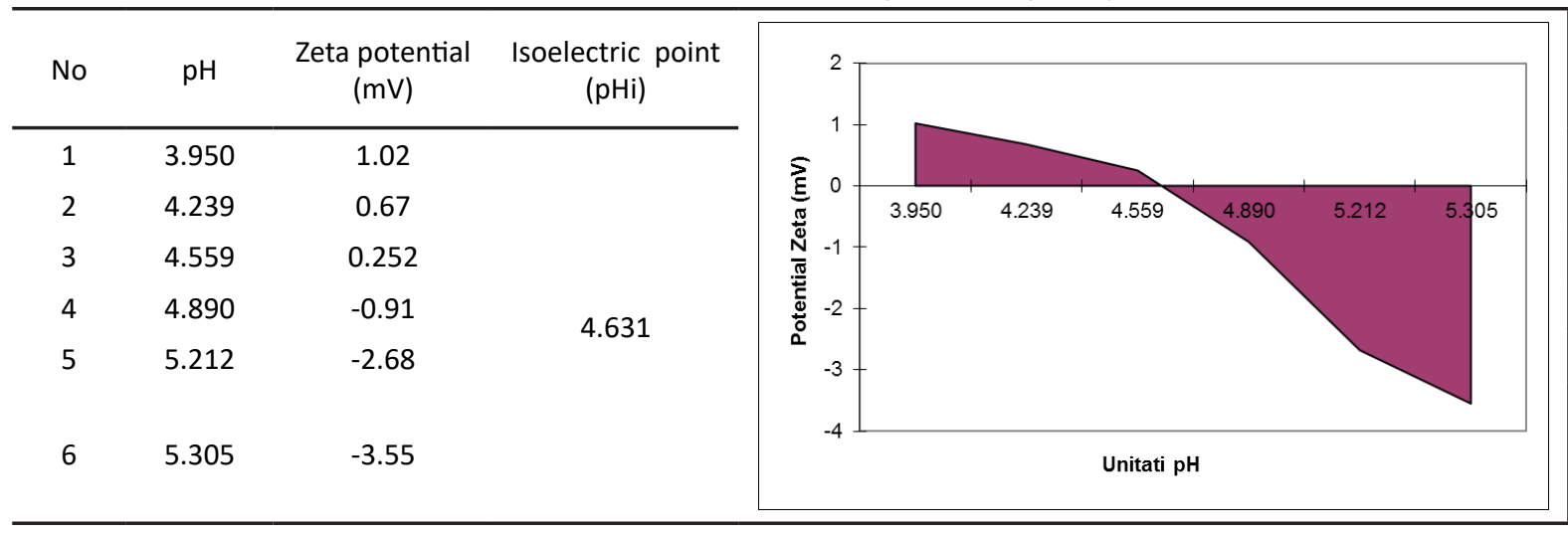

Table 16: Determination of isoelectric point - Hydrolysate H08-4

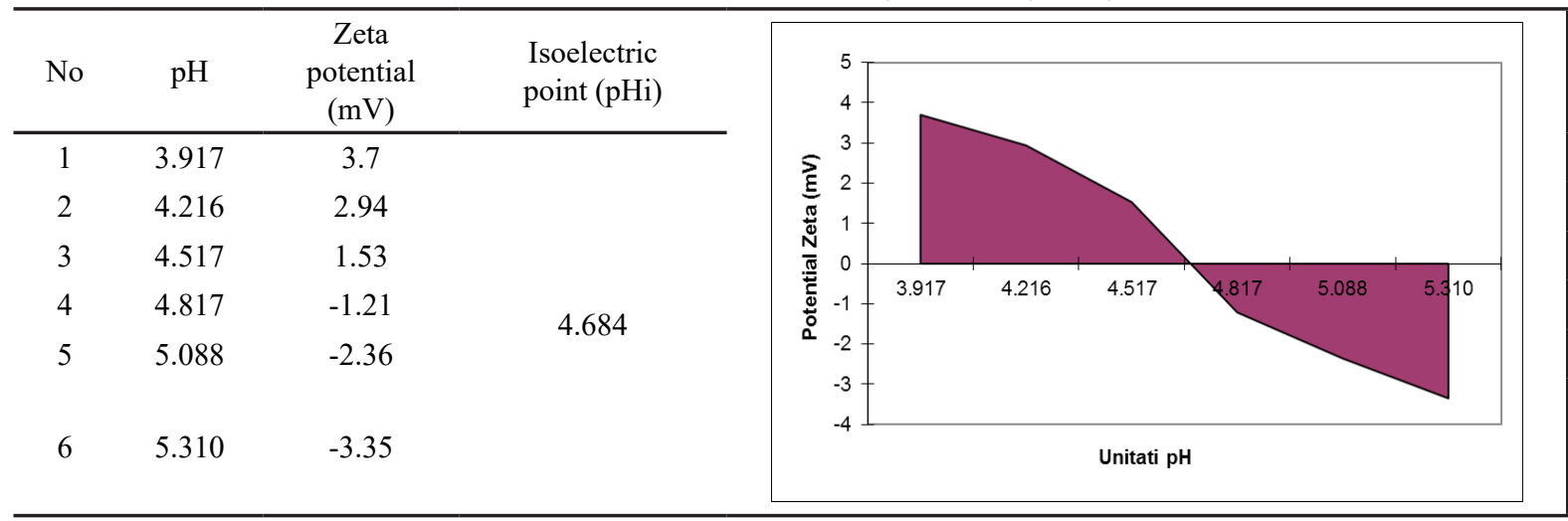


Table 17: Determination of isoelectric point - Gelatin capsules

$1 \%$ gelatin solution in water (gelatin capsules)

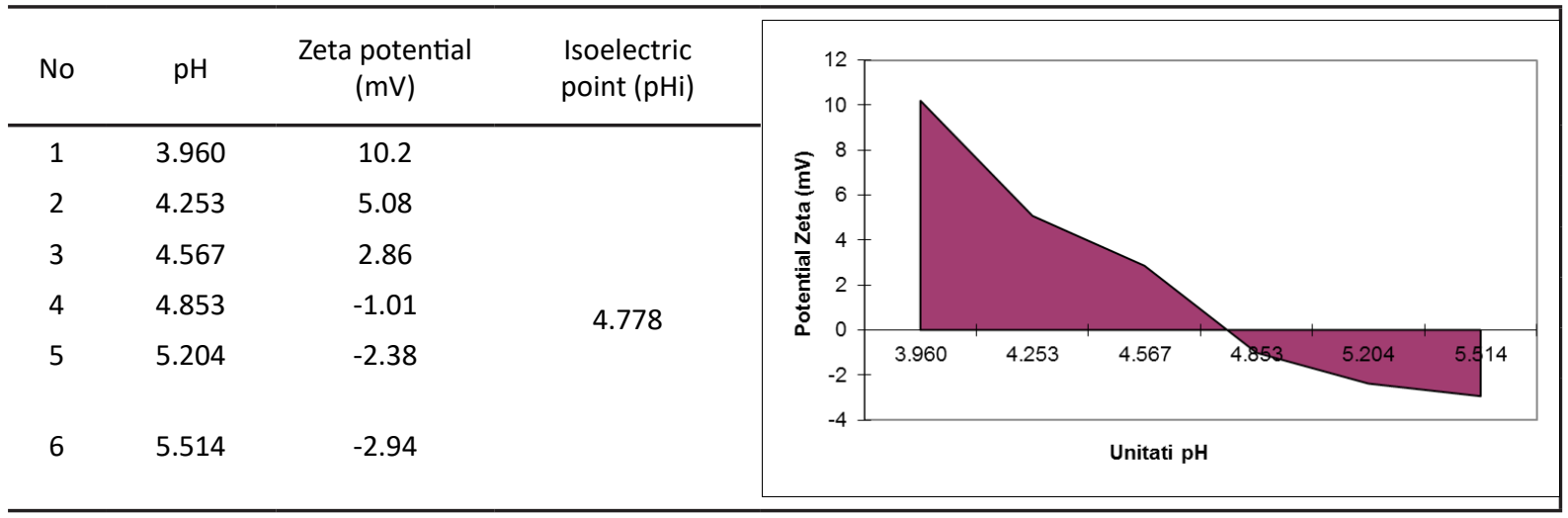

The isoelectric points determined for soluble collagen hydrolysates and gelatin capsules are reproducible and in accordance with theoretical data in the literature.

\section{CONCLUSIONS}

The analytical method to determine the isoelectric point of protein solutions was performed based on electrophoretic mobility of solutions by determining Zeta potential depending on $\mathrm{pH}$.

The technique used to measure electrophoretic mobility in the Malvern Zetasizer Nano Series is the Laser Doppler Velocimetry (LDV).

For all measurements, a $40 \mathrm{~V}$ field was applied over a $10 \mathrm{~mm}$ electrode spacing at $25^{\circ} \mathrm{C}$.

Three repeated measurements were performed on each sample to verify repeatability of the results.

All measured electrophoretic mobilities were transformed into Zeta potential using the Smoluchowski formula.

The method has been checked to ensure reproducibility and is supported by determinations on samples of soluble proteins, namely $\mathrm{HO} 8$ collagen hydrolysates and gelatin capsules, from the Collagen Department of ICPI.

Statistical calculations were performed in Excel 2010, used both to calculate the isoelectric points, standard deviation, bias, repeatability, reproducibility, fidelity and accuracy of the method. All statistical tests were performed at a confidence level of $95 \%$ and $k=2$.

From the calculation of the performance parameters of the studied method, the following is noted:

- The accuracy of the method is $99.8121 \%$ and represents the closeness between the real value and the value found in the analyzed sample, based on an established criterion of $99 \pm 2 \%$;

- The calculated standard deviation is $0.0094 \mathrm{pH}$ units;

- The reliability of the method is $0.2011 \%$, representing the degree of closeness between the results;

- The repeatability is equal to $0.026 \%$ and is a measure of the degree of scattering of the results, within a confidence interval;

- The isoelectric point determined by this method is in the range of $4.6912 \pm 0.001$ $\mathrm{pH}$ units, as compared to 4.7 as specified in the literature;

- The performance parameters comply with acceptability criteria, the method is appropriate for the proposed purpose and as a result it was validated.

\section{Acknowledgements}

This work was financially supported by $\mathrm{MCl}$ in the frame of Nucleus Program INOVA-TEX-PEL, 
contract 26N/2016, project code PN 16340404.

\section{REFERENCES}

1. Loeb, J., Proteins and the theory of colloidal behavior, New York and London, McGraw-Hill Book Company, Inc., 2nd ed., 1924.

2. Audain, E., Ramos, Y., Hermjakob, H., Flower, D.R., Perez-Riverol, Y., Accurate Estimation of Isoelectric Point of Protein and Peptide Based on Amino Acid Sequences, Bioinformatics, 32, 6, 2016, 821-827, https://doi.org/10.1093/ bioinformatics/btv674.

3. Highberger, J.H., The Isoelectric Point of Collagen, J Am Chem Soc, 61, 9, 1939, 23022303, https://doi.org/10.1021/ja01878a010.

4. Tanaka, S., Hata, R.I., Nagai, Y., Two-dimensional Electrophoresis of the $\alpha$-Chains of Collagens and its Application to the Determination of their Isoelectric Points, Coll Relat Res, Vol. 1, 1981, 237-246.

5. Measuring Protein Isoelectric Point Using The Zetasizer Nano ZSP - Method and Comparison with other Techniques - Malvern Application Note MRK1650-01, 2013.

6. Michaelis, L., Die Wasserstoffionenkonzentration, Berlin, J. Springer, 2nd ed., 1924.

7. Sorensen, S.P.L., Linderstrom-Lang, K., Lund, E., J Gen Physiol, 8, 1925-28, 543.

8. Michaelis, L., Grineff, W., Bioch Zeitschr, 41, 373, 1912.

9. Kraemer, E.O., Dexter, S.T., J Physic Chem, 1927, 31, 764.

10. Davis, C.E., Sheppard, S.E., Briefer, M., Ind Eng Chem, Analytical Edition, 1, 56, 1929, https://doi.org/10.1021/ac50065a029.

11. Hudson, J.H., Sheppard, S.E., A Contribution to the Preparation of Standard Gelatin, Ind Eng Chem, 21, 3, 1929, 263-264, https://doi. org/10.1021/ie50231a021.

12. Hitchcock, D.I., The Isoelectric Point of a Standard Gelatin Preparation, J Gen Physiol, 14, 6, 1931, 685-699.

13. Sheppard, S.E., Houck, R.C., J Physic Chem,
34, 273, 1930, 2187.

14. Hunter, R.J., Zeta Potential in Colloid Science, London, 1981.

15. Zetasizer Nano Series User Manual, Malvern Instruments Ltd. 2013.

16. Kaszuba, M., Corbett, J., Watson, F.M., Jones, A., High-concentration zeta potential measurements using light-scattering techniques, Malvern Instruments Ltd, Worcestershire WR14 1XZ, UK, 2009.

17. Leão Andrade, Â., Maria Fontes Ferreira, J., Zacarias Domingues, R., Zeta Potential Measurement in Bioactive Collagen, Materials Research, 7, 4, 2004, 631-634, https://doi. org/10.1590/S1516-14392004000400018.

18. Janus, J.W., Kenchington, A.W., Ward, A.G., Rapid method for the determination of the isoelectric point of gelatin using mixed bed deionization, in "The Science and Technology of Gelatin" (A.G. Ward \& A. Courts, Eds.), 1951, 31-72.

19. Berg, J.M., Tymoczko, J.L., Gatto, G.J., Stryer, L., Biochemistry, 8th Ed., W.H. Freeman: New York, NY, 2015.

20. Pace, C.N., Grimsley, G.R., Scholtz, J.M., Protein Ionizable Groups: pK Values and Their Contribution to Protein Stability and Solubility, J Biol Chem, 284, 20, 2009, 13285-13289, https://doi.org/10.1074/jbc.R800080200.

21. Thurlkill, R.L., Grimsley, G.R., Scholtz, J.M., Pace, C.N., pK Values of the Ionizable Groups of Proteins, Protein Sci, 15, 2006, 1214-1218, https://doi.org/10.1110/ps.051840806.

22. Macovescu, G., Chelaru, C., Ignat, M., Albu, L., Gurau, D., Method for Determining the Isoelectric Point of Protein Solutions, Proceedings of IV International Leather Engineering Congress Innovative Aspects for Leather Industry, Oct 19 - 20, 2017, IzmirTurkey, 257-261, ISBN 978-605-338-22-5.

23. Johlin, J.M., The Isoelectric Point of Gelatin and its Relation to the Minimum Physical Properties of Gelatin, J Biol Chem, 86, 1930, 231-243. 
24. Kozlowski, L.P., IPC - Isoelectric Point Calculator, Biol Direct, 11, 55, 2016, https:// doi.org/10.1186/s13062-016-0159-9.
(C) 2018 by the author(s). Published by INCDTPICPI, Bucharest, RO. This is an open access article distributed under the terms and conditions of the Creative Commons Attribution license (http:// creativecommons.org/licenses/by/4.0/). 